\title{
The Cultural Resources of the Teachers College Library
}

IBRARIANS will agree that the main obL jective of the college library is to make its services contribute as effectively as possible to the instructional program of the college. In addition to this primary task, every college librarian has the opportunity and responsibility to present and encourage the use of extracurricular or cultural resources. In fact, it is sometimes difficult to tell where class assignments end and individual interests begin. Among the nonbook materials which libraries are acquiring and suggesting to students one finds picture collections. These may include attractively framed pictures ready to hang on the wall which are loaned or rented to students for/ use in their dormitory rooms. If rental fees are permitted, the pictures may be fairly expensive reproductions; if they are free, they can be simply and inexpensively mounted instead of framed. The Museum of Modern Art in New York advertises a picture changer made of plywood and plexiglas in which prints can be displayed. Before the war, there was one club which sold a "button-in frame" and a collection of prints which the owner could change from time to time. Poetry broadsides from the Enoch Pratt Free Library in Baltimote make attractive wall or bulletin board displays and they can be ordered in quantity and sold in the library itself. A dormitory room or school room can be brightened by one of these colorful, inexpensive sheets. Young people now have their own collections of phonograph records and are familiar with the classic and modern compositions. A library collection should include not only a wide variety of music discs but stories and speech records and linguaphone sets for foreign language study. Somewhere in the library or college there should be a quiet room with a phonograph where these records can be played.

Few libraries have book budgets sufficient for their needs. By the time books have been purchased l for required reading or to strengthen weak spots in the collection, there is little money remaining for leisure time reading. Some college libraries place current fiction and nonfiction in a rental collection. When these books have collected fees equal to the initial cost, they are placed in an unclassified popular book collection and circulated free of charge. As they become worn or shabby they are discarded unless they are considered worth rebinding and adding to the permanent collection. Where rental fees are not permitted, a small collection of reprint editions makes an attractive and popular supplement to the regular library. Many librarians testify to the value of dormitory collections, and reprint editions can be used in these. Robert M. Orton's Catalog of Reprints in Series is as suggestive and interesting to students as to librarians. The $P u b$ lisher's Weekly recently called attention to the need for a classics library in an inexpensive series, about 100 to I50 basic works which have tended to shape our modern world. Books of this sort would be useful 
in dormitory collections as well as in the general collection. There should be a revival of interest in personal libraries. Several colleges in the past have given yearly prizes to the student who acquired the best collection of books and who could discuss the basis for his choice. There might even be a limit to the amount of money spent by the student so that the importance of searching for inexpensive or secondhand books would be contrasted with mere buying expensive editions. Not that fine type and illustration should be denied to students. Every library should have a few examples of this kind, and students should know about the Heritage Book Club or other clubs through which they can buy moderately priced editions with unusual illustrations and good print.

All these collections must be made accessible and brought to the attention of the students. Book jackets, growing more colorful and garish each day, attract attention and advertise their books. This was proved by a little experiment of watching three books in our browsing room collection. When they were returned to their places on the shelves minus jackets, they were lost in the rows of other colorless book bindings. As soon as we put on the bright jackets and placed them on display they were borrowed almost immediately.

Since students from teachers colleges eventually teach children, they should have an opportunity to see many children's books. They should be encouraged to read these books which they in turn will have their children read later on. It will be interesting to watch the new Teen-Age Book Club which was inaugurated in September by Pocket Books. Five twenty-five-cent editions of children's books will be published each month in an attempt to encourage young people to own good books as well as read them. In her 1946 Bowker lecture,
Books in Search of Children, Louise Seaman Bechtel describes the librarian as the defender of books and the defender of the individual reader against standardization. She begs them, also, to reach out into their communities, to use more tool books of information, and to have more men give book talks to growing boys. All librarians of teachers colleges should read this challenging essay.

\section{Education as a Subject}

Education as a subject should not be excluded from a consideration of the cultural resources of the library. Today education is front page news and the rush of veterans to colleges all over the United States makes education everybody's business. During the past two years several books on education became best sellers, notably Van Doren's Liberal Education and Barzun's Teacher in America. Barzun's book sends the reader back to William James to enjoy rereading the volume, Talks to Teachers on Psychology. An answer to the question "of what use is college training" can be found in the essay, "Social Value of the College Bred," in William James' volume, Memories and Studies. Sidney Hook's new book, Education for Modern Man, will provoke many arguments; his chapter analyzing the good teacher deserves special attention from librarians as well as teachers. All librarians have heard of the Harvard report, General Education in a Free Society, and no doubt have read at least parts of it. They would find rewarding the excellent review and criticism of this document by Marjorie Nicolson in the spring 1946 issue of the Yale Review. Interest is centered on plans under way at other colleges, one of which, A College Program in Action, has just been published by Columbia College. Answers to questions about similar plans may be found in a brief discussion of those at Yale, 
Princeton, and Johns Hopkins in the December 1945 Association of American Colleges Bulletin. An earlier Harvard report, The Training of Secondary School Teachers Especially with Reference to English, has been labeled required reading by Louise Seaman Bechtel in her lecture mentioned earlier. Librarians of teachers colleges will find especially rewarding the chapter, "Existing Dilemmas," dealing with the disharmony which now exists between the liberal arts college and the teachers college. Both are analyzed and criticized and the committee concludes that "any improvement in the training of teachers depends not only on an overhauling of educational faculties but also on a re-examination of teaching in the liberal arts."

\section{Books About Rural Schools}

The teachers college librarian should be aware of these movements in the college world; she should have at least a bowing acquaintance with the works discussing the basic philosophy of education and should be able to discuss them with students. But she should also examine or skim, if not read, more practical books which can aid the beginning teacher. These items have their place, too, even though they may not be classified as cultural. A recent one, $M y$ Country School Diary by Julia Weber, has been reviewed in the weekly book reviewing magazines. As the subtitle indicates, it is an account of an adventure in creative teaching in a rural school. It calls to mind an earlier book, Living and Learning in a Rural School by Genevieve Bowen. Both books are readable and are filled with definite practical suggestions for the rural school teacher. A novel, Fair Is the Morning by Loula Erdman, is a vocational story intended for older girls. Although the romance is obvious, the story points the thesis that rural school teachers should be espe- cially trained for their work. It, too, has a message for these thousands of teachers who will teach more than four million country boys and girls in one- or two-room schools.

The library can have a large and wellselected collection of books attractively displayed with all the library techniques running smoothly, but there is still need for the librarian who has read widely, likes to read, and is willing and eager to talk about her reading. Joseph $\mathrm{L}$. Wheeler, in his report, Progress and Problems in Education for Librarianship, calls for more book appreciators. He says, "It is essential to bring back into the entire library philosophy, in the field and in the schools, a renewed respect and a real knowledge and understanding of books. Every library with a staff of a dozen needs to include one such personage who can spread enthusiasm and knowledge among community groups as well as among patrons and staff within the building." $\mathrm{Li}$ brarians are bombarded by print-professional journals, book reviews, reports, educational materials. When can they find time to read real books? Is it only at night? The reading diet must be varied to include some profound books which require long periods of reading. We can't expect to absorb in a day what it has taken an author a lifetime to learn and produce. Although we all wish for that complete simplicity and absence of hurry pictured in Thus Far and No Further by Rumer Godden, as life today is geared in a library there seems to be no other way but to steal the time to read. Librarians must not fail to do for themselves, however, what they so valiantly try to do for others. Nor can this reading be passive and solitary. A returned soldier, telling about his reading experiences in the Army, voices the important observation that a reasonable amount of reading is fine but that too much solitary reading is a vice and 
rots the mind. Librarians as well as students need to discuss their reading in order to deepen their reactions and review the ideas gleaned from the books. Talking about books read impresses them on the reader's mind and may entice others to share in the discovery. This talk should not consist of nebulous generalities but definite ideas and facts expressed with intelligent, enlightened enthusiasm. Librarians should discuss their reading with members of the faculty as well as with students, for they can enrich their own knowledge of books in other subjects by conversation with these well-informed people. They should be ready to receive as well as to give.

Too often in current novels a librarian is pictured as devoid of personality, lacking in imagination, ungracious, frustrated, a "sourpuss." Rules must be enforced, of course -though all rules can be broken at timesbut firmness with a smile and expression of regret and with some suggestion of a substitute measure is good strategy, far better than "pursed lips, the tone of suspicion, the pouncing manner," Recruiting for library service, a subject which is receiving attention right now, is closely connected with the librarian's personality. It is futile to expect young people to be interested in the library profession if their experiences do not include contacts with alert librarians. Too seldom have they had an opportunity to observe the ramifications of library work, so they think it includes nothing but handing out books and keeping students quiet. The teachers college library should be aware of the opportunity for attracting superior students to librarianship. The best advertisement for the library profession is a well-run library staffed by gracious, personable, informed, enthusiastic librarians.

"Termites of the Stacks"

The librarian of the small teachers col- lege is justified in complaining that there is little time left from the myriad duties connected with running a library for reading of this kind. This excuse holds for librarians of larger libraries, too. However, we seem to manage to find time for that which we really enjoy, whether it be bridge, movies, concerts, theatres, or books. It does seem logical that all librarians should find some time for books, not only for professional advancement, but for personal enjoyment and enrichment. Recently in the Saturday Review of Literature John Mason Brown "snarled," as he put it, at the Ph.D. who rests on the laurels of that degree. With his colorful vocabulary and startling figures of speech Mr. Brown riddles these "Termites of the Stacks." As one reads amusedly his essay it may be realized that the word librarian could be easily substituted for teacher and library training tor Ph.D., and perhaps there was salutary criticism here for our own profession. A brief quotation from his shrewd appraisal will indicate its appropriateness.

I resent them when they presume to deaden by their touch that which was meant to provide pleasure, supply beauty, comment on life, and interpret what is most vital in man's dreams, hopes, agonies, passions, ecstasies, and delights. ... To the end of their days, the drones of whom I was thinking persist in mistaking the housework which must be done before the feast is served for the feast itself. ... What they offer in the place of food and drink is their own soiled dusters. ... They have become wedded to the stacks, those dreary ones, attacking the books they use there as termites rather than as tasters. Although they live, they are not alive. They are juiceless and joyless; useless but active. Although in every sense of the word they bore, they fail to illumine. . . They are small people unaware of the dimensions of the books with which they deal. ... They can annotate but not appreciate; quote but not interpret; catalogue but not enjoy; observe but not par(Continued on page 23I) 
should be his responsibility to establish policies and procedures and to see that they are carried through. Any variations should be made only with his cognizance.

2. Supervision of departmental library cataloging should be centered in the head of the central catalog department or in a senior cataloger responsible to the head. This supervisor should not only make personal contacts with the departmental library staff for consultation but should also inspect the departmental catalogs at regular and frequent intervals. He should advise and instruct any of the departmental library staff who work with the catalog; it would be helpful for those staff members to have an orientation period in the central catalog department.

3. A written code of practice is desirable for the central catalog department and also for the departmental library insofar as it is directly concerned.

4. It would be interesting to have evidence of the claim of economy for centralized cataloging. Studies in cataloging costs and comparisons of costs for various types of organization would be of value.

5. As already indicated, the present study has been limited in scope. Further investi- gation might be concerned with cataloging for departmental libraries in the larger institutions where every variety of departmental library and every type of organization, with their special problems, usually exist. This investigation also might consider the viewpoint of the departmental library.

\section{Libraries Which Contributed Information}

University of Alabama Library
University of Arkansas Library
Bryn Mawr College Library
University of Colorado Library
University of Florida Library
Fordham University Library
Georgetown University Library
University of Georgia Library
Hamilton College Library
Lehigh University Library
Louisiana State University Library
Miami University Library
Mount Holyoke College Library
University of Notre Dame Library
Pennsylvania State College Library
University of Pittsburgh Library
Purdue University Library
Rutgers University Library
Smith College Library
University of Tennessee Library
Vassar College Library
University of Vermont Library
Wellesley College Library
Williams College Library

University of Alabama Library

University of Arkansas Library

Bryn Mawr College Library

University of Colorado Library

University of Florida Library

Fordham University Library

Georgetown University Library

University of Georgia Library

Hamilton College Library

Lehigh University Library

Louisiana State University Library

Miami University Library

Mount Holyoke College Library

University of Notre Dame Library

Pennsylvania State College Library

University of Pittsburgh Library

Smith College Library

University of Tennessee Library

Vassar College Library

University of Vermont Library

Williams College Library

\section{The Cultural Resources of the Teachers College Library}

\section{(Continued from page 224)}

ticipate; and burrow without coming up with anything worthy of the search. They have a genius for digging diligently and keeping their shovels empty. ... The truth is that they are the barnacles of beauty and pleasure, of literature and the drama. Like barnacles they attach themselves not only to the bottom of the crafts to which they cling but ride forever submerged on the outside of the hull. Their final $\sin$ is that they deaden what they touch, managing to make what should be interesting as dull as they are themselves. ... ${ }^{1}$

\footnotetext{
${ }^{1}$ Brown, John Mason. "Termites of the Stacks." Saturday Reviev of Literature. 29:34-36, May i1, 1946.
} 